\title{
Occurrence of heavy rainfall around the confluence line in monsoon disturbances and its importance in causing floods
}

\author{
G NAGESWARA RAO \\ Department of Meteorology \& Oceanography, Andhra University, Visakhapatnam 530003, India. \\ e-mail: raongantasala@yahoo.com
}

\begin{abstract}
It is well known that heavy rainfall occurs in the southwestern sector of the monsoon depressions due to strong convergence in that sector. By examining the rainfall distribution associated with the monsoon disturbances (lows and depressions) in one of the central Indian river basins, 'Godavari', the author found that when the disturbance-centre is away from the basin, heavy rainfall may also occur in the basin area close to the confluence line and cause severe floods in the river. The confluence line is the zone of convergence between the northeasterlies to the west of the disturbance centre and the monsoon westerlies. This study further reveals the importance of the position and movement of the confluence line with respect to the basin, on which the intensity and the raising period of the resulting flood depend.
\end{abstract}

\section{Introduction}

Monsoon disturbances are the important synoptic systems that cause floods in the central Indian rivers, during the southwest monsoon season (JuneSeptember). On an average, six depressions form in the Bay of Bengal during the three months of July to September (Rao and Jayaraman 1958). These disturbances generally move west-north-westwards along the Gangetic valley after their formation at the head of the Bay of Bengal, up to the central parts of the country before weakening (Rao 1976). It is well known that heavy rainfall occurs in the southwestern sector of the monsoon depressions due to strong convergence in that sector. It has also been reported by several authors that heavy rainfall occurs over an area to the left of the storm track (Pisharoty and Asnani 1957; Lal 1958; Bedekar and Benarjee 1969) extending between 200 and $800 \mathrm{~km}$ from the centre (Venkataraman et al 1974 and Chowdary and Gaikwad 1983). In the present paper, the author examined the rainfall distribution in the Godavari river basin, associated with the flood-producing monsoon disturbances during 1962-1990 and revealed the importance of the heavy rainfall that occurred around the confluence line in causing severe floods in the Godavari river.
The Godavari is the largest peninsular river in India. It originates in the Western Ghats, near Triambak (figure 1) in Nasik district of Maharashtra. It flows in a southeasterly direction across the states of Maharashtra, Karnataka, Madhya Pradesh, Orissa and Andhra Pradesh and joins the Bay of Bengal about $70 \mathrm{~km}$ east of Dowlaiswaram in Andhra Pradesh. The Godavari river system with its major tributaries of Purna, Manjra, Penganga, Wardha, Wainganga, Pranhita, Indravati and Sabari, is spread over an area of $312870 \mathrm{~km}^{2}$ across 30 districts of the above five states in central India (figure 2).

The Godavari basin receives an average rainfall of $92.3 \mathrm{~cm}$ during the monsoon season (June-September) which is about $85 \%$ of its annual rainfall. The monsoon rainfall in the Godavari basin varies largely in time and space. The author (Nageswara Rao 1998) studied the interannual variations of the monsoon rainfall in the Godavari basin in relation to the Southern Oscillation (SO) and found that the monsoon rainfall in Godavari has a significant negative correlation with SO. The spatial distribution of rainfall in the Godavari basin is also not uniform as shown in figure 2 , in which the mean monsoon rainfall in the 30 districts of the basin for the period 1901-50 is presented. The monsoon rainfall is as low as $42.0 \mathrm{~cm}$

Keywords. Monsoon disturbances; confluence line; heavy rainfall, floods. 


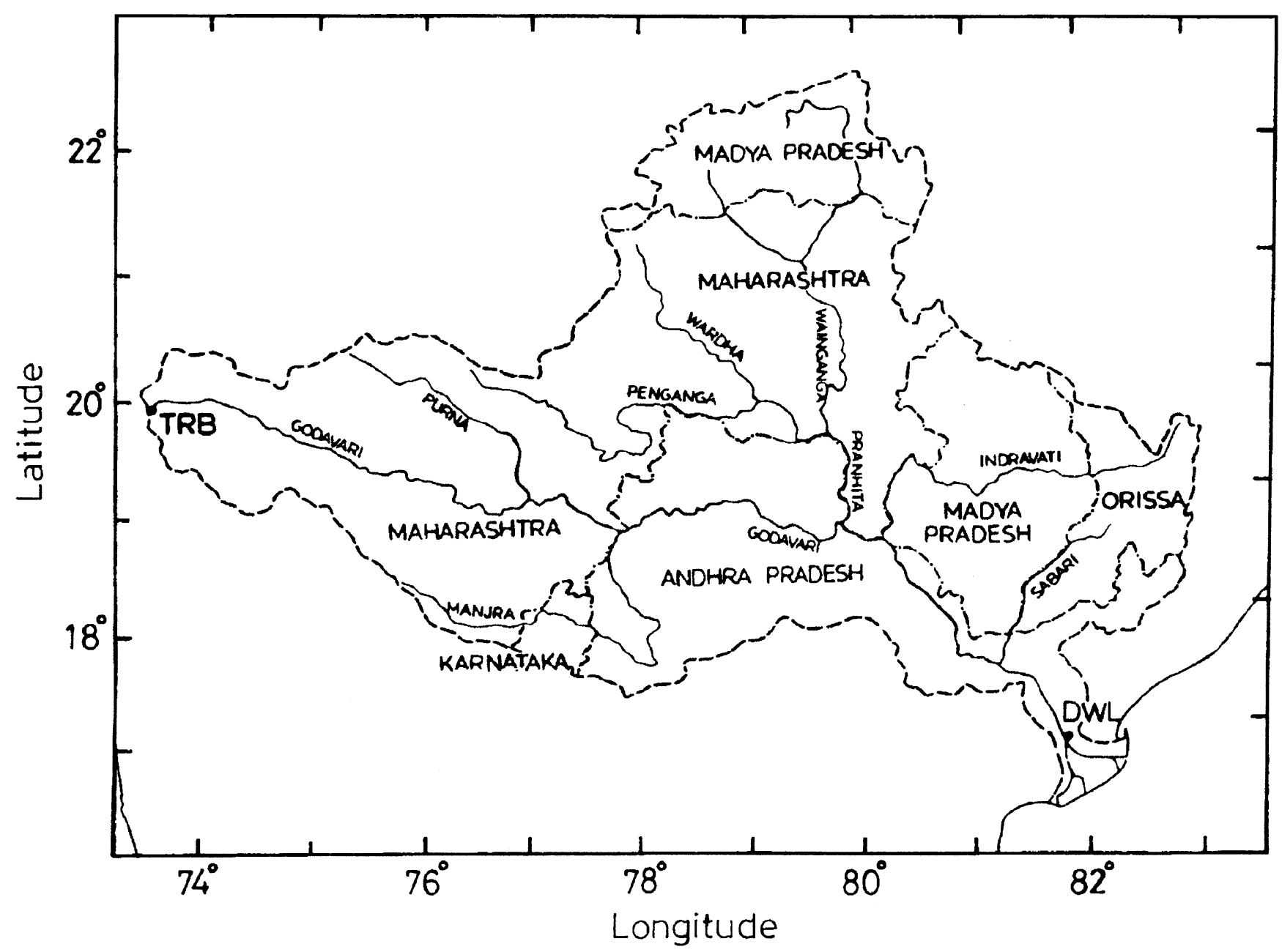

Figure 1. Catchment area of Godavari river system with major tributaries. State boundaries are indicated by dot-dashed line. TRB - Triambak, DWL - Dowlaiswaram.

in the western districts, which lie in the shadow zone of the Western Ghats. It gradually increases towards the east and north. The eastern and northern districts of the basin receive heavy rainfall as high as $120.0 \mathrm{~cm}$ during the monsoon season mainly due to the passage of monsoon disturbances. These monsoon disturbances contribute about 50 to $65 \%$ of the seasonal rainfall in the basin. It has been observed (Nageswara Rao 1999) that there is a significant difference in the number of disturbance-days and their rainfall contribution to the Godavari basin in the years of the highest and the lowest rainfall. The ratio of the disturbance-days and their associated rainfall in the basin in the highest and the lowest rainfall years is observed to be 1.4 and 1.9 respectively, while the ratio of the total seasonal rainfall in these two years is also 1.9. When the monsoon disturbances move slightly south of their normal track in a west-northwesterly direction close to the basin, they produce heavy to very heavy rainfall in different parts of the Godavari basin, resulting in severe floods. Thus, while the river flows from northwest to southeast and joins the Bay of Bengal, the monsoon disturbances after their formation in the Bay of Bengal move towards the upstream. The intensity and duration of the resulting flood depend on the intensity, duration and movement of the rainstorm which in turn depends on the location and movement of its corresponding synoptic system with respect to the basin. Several authors (e.g., Ramaswamy and Subba Rao 1980; Ramaswamy 1987; Dhar 1987; Subbaramayya and Nageswara Rao 1989; and Nageswara Rao and Subbaramayya 1991) studied the hydrometeorological aspects of some floods in the Godavari.

\section{Data}

The daily river discharge data of 22 flood cases during 1962-90 at Dowlaiswaram, which is situated near the river mouth (figure 1), were obtained from the irrigation department at Dowlaiswaram. If the river discharge at Dowlaiswaram exceeds 19.8 thousand cumecs $\left(\mathrm{m}^{3} / \mathrm{s}\right)$, the irrigation department issues a flood warning. The date of peak flood and the peak flood discharge in the above 22 flood cases are listed in table 1 . For examining the synoptic systems and their 


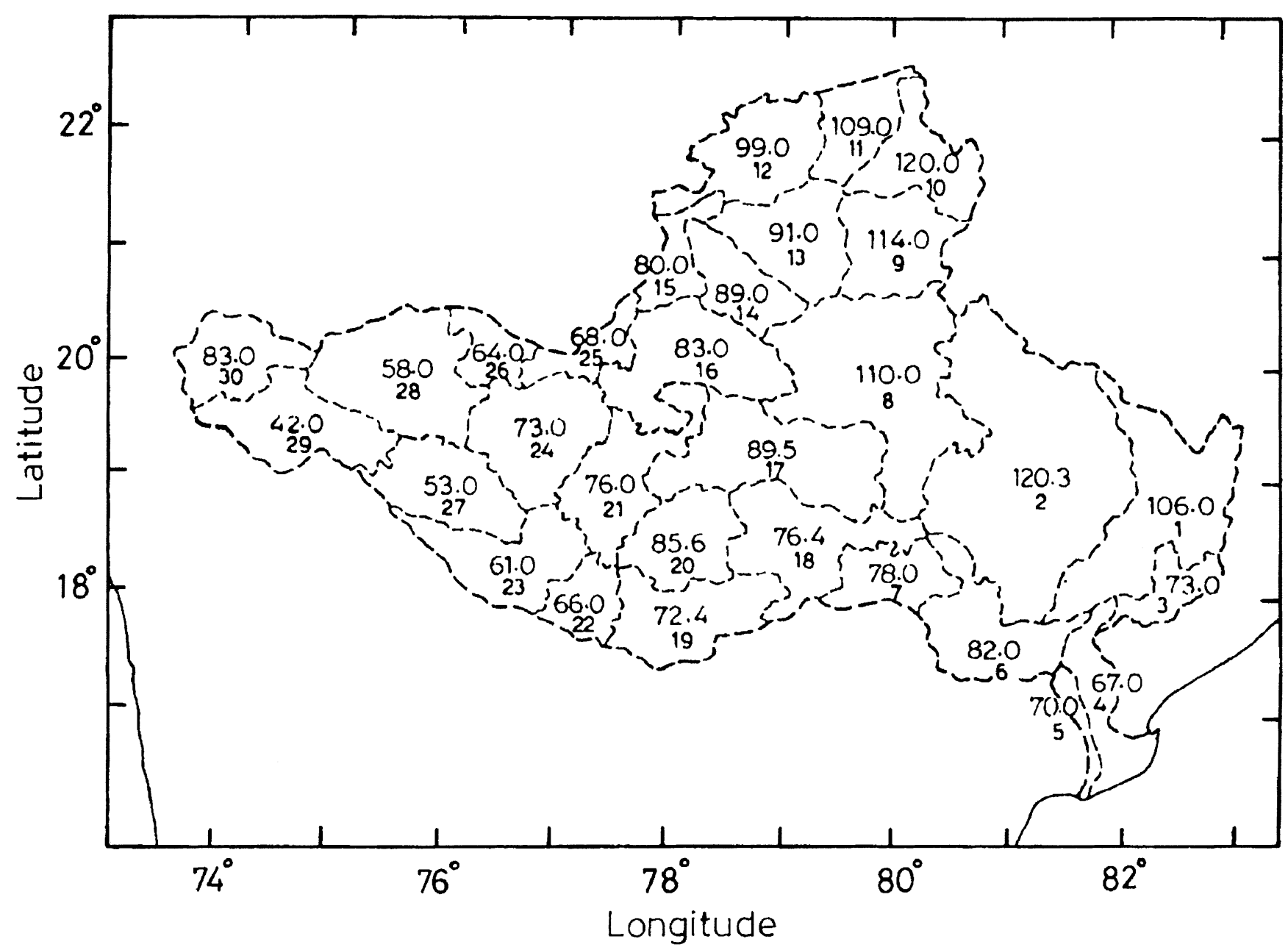

Figure 2. Mean monsoon rainfall $(\mathrm{cm})$ in the 30 districts of Godavari basin during 1901-50.

Table 1. List of flood cases considered in the study (in chronological order).

\begin{tabular}{|c|c|c|c|c|}
\hline Case No. & Date of peak flood & $\begin{array}{l}\text { Peak flood discharge } \\
\text { (thousand cumecs) }\end{array}$ & Synoptic system & Area of heavy rainfall \\
\hline 1 & 16.8 .1962 & 37.1 & $\mathrm{~L}$ & close to the centre \\
\hline 2 & 22.9 .1962 & 49.8 & $\mathrm{D}$ & around C.L. \\
\hline 3 & 26.9 .1964 & 25.3 & $\mathrm{D}$ & around C.L. \\
\hline 4 & 8.9 .1966 & 62.6 & $\mathrm{~L}$ & east of C.L. \\
\hline 5 & 29.7.1967 & 26.9 & $\mathrm{~L}$ & close to the centre \\
\hline 6 & 11.9 .1969 & 25.2 & $\mathrm{D}$ & close to the centre \\
\hline 7 & 23.9 .1969 & 35.7 & $\mathrm{D}$ & east of C.L. \\
\hline 8 & 23.8 .1970 & 56.7 & $\mathrm{D}$ & west of C.L. \\
\hline 9 & 08.7 .1972 & 21.9 & $\mathrm{D}$ & close to the centre \\
\hline 10 & 12.7 .1973 & 19.9 & $\mathrm{D}$ & close to the centre \\
\hline 11 & 17.7.1975 & 27.0 & $\mathrm{~L}$ & close to the centre \\
\hline 12 & 23.7.1976 & 54.4 & $\mathrm{~L}$ & around C.L. \\
\hline 13 & 26.8 .1977 & 23.3 & $\mathrm{D}$ & around C.L. \\
\hline 14 & 18.8 .1978 & 40.5 & $\mathrm{D}$ & around C.L. \\
\hline 15 & 7.8 .1979 & 30.6 & $\mathrm{~L}$ & close to the centre \\
\hline 16 & 13.8 .1981 & 42.2 & $\mathrm{D}$ & close to the centre \\
\hline 17 & 16.8 .1983 & 57.9 & $\mathrm{~L}$ & around C.L. \\
\hline 18 & 16.8 .1986 & 99.3 & $\mathrm{D}$ & east of C.L. \\
\hline 19 & 4.10 .1988 & 36.7 & $\mathrm{D}$ & close to the centre \\
\hline 20 & 27.7 .1989 & 43.1 & $\mathrm{D}$ & close to the centre \\
\hline 21 & 4.9.1989 & 27.9 & $\mathrm{~L}$ & west of C.L. \\
\hline 22 & 2.9.1990 & 61.0 & $\mathrm{~L}$ & east of C.L. \\
\hline
\end{tabular}

L - Low; D - Depression; C.L. - Confluence line. 

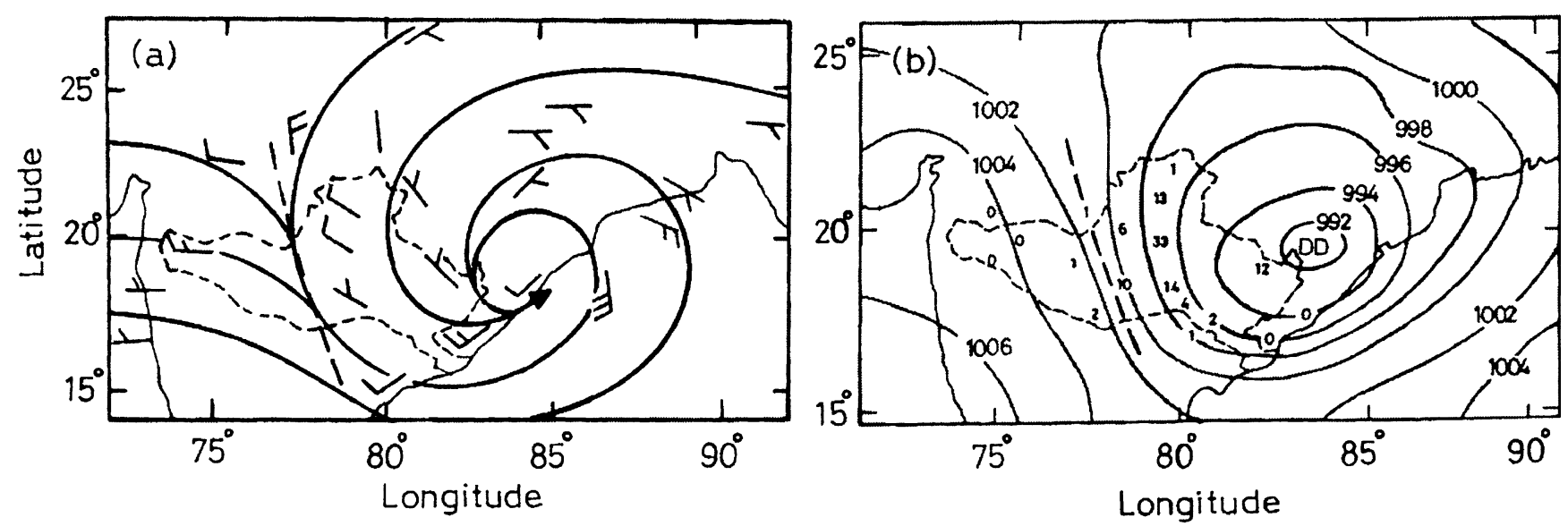

Figure 3. Identification of the confluence line (thick dotted line) on streamline chart (a) and on surface pressure map (b).

associated rainfall in the Godavari basin, the surface synoptic charts published in the Indian Daily Weather Reports have been used. However, in the cases during the period 1963-84, the daily district average rainfalls of the 30 districts in the basin are plotted on the synoptic charts.

The confluence line (figure $3 \mathrm{a}$ ) is the zone of convergence between the monsoon westerlies blowing from west-northwesterly/northwesterly direction and the northeasterlies in the northwestern sector of the cyclonic system turning northerly downstream. It can be easily identified on the streamline charts (figure 3a). The confluence line indicated by a thick dotted line can also be identified on the surface pressure charts along the zone of isobar convergence (figure $3 b$ ).

\section{Results and discussion}

The synoptic systems that are responsible for the floods and the area of heavy rainfall in each of the 22 cases are given in table 1 . Of the 22 cases considered, in 10 cases the area of heavy rainfall in the basin was relatively closer to the disturbance-centre. In the remaining 12 cases, when the centre of the system is away from the basin area, heavy rainfall occurred in the basin area close to the confluence line (C.L.). Hence only these 12 cases are considered for further analysis. It can be seen from table 1 that, of the 10 cases in which the heavy rainfall occurred close to the disturbance-centre, in 4 cases the synoptic system is a low $(\mathrm{L})$ while in the remaining 6 cases, it is a depression (D). Similarly, in the other 12 cases where the heavy rainfall was associated with the confluence line, there are 5 low pressure systems and 7 depressions. The rainfall distribution along with the surface pressure pattern on the day of the maximum rainfall in the 12 cases, in which the heavy rainfall occurred close to the confluence line are presented in figures 4 to 6 . The confluence line on these pressure maps is identified along the zone of isobar convergence. In figures 4 to 6 , this confluence line is indicated by a thick dotted line and the area of heavy rainfall $(>5 \mathrm{~cm})$ has been hatched.

Of the 12 flood cases considered in the study, in 6 cases (figure 4), the heavy rainfall had occurred around the confluence line, in 4 cases (figure 5) it is to the east of the confluence line and in 2 cases (figure 6) the heavy rainfall is to the west of the confluence line. This relative position of the heavy rainfall area may depend on the upper air conditions, such as the vertical extent and slope of the confluence line etc. and needs further investigation. It can be seen from table 1 that in the case of floods resulting from the systems in which the heavy rainfall has occurred close to the disturbance-centre, the peak flood discharge ranges from 20.0 to 43.0 thousand cumecs. In the case of the floods resulting from heavy rainfall was associated with the confluence line, it ranges from 28.0 to 99.0 thousand cumecs. Thus, the floods resulting from the systems in which the heavy rainfall was associated with the confluence line are in general more severe than those associated with the systems in which the heavy rainfall occurred close to the centre. It can be further observed from the same table, that in all the 4 cases where the heavy rainfall has occurred to the east of the confluence line, the Godavari river experienced most severe floods, in which the peak flood discharge ranges from 35.7 to 99.3 thousand cumecs. This is because in the 'east of C.L.' cases (figure 5) the area of heavy rainfall is situated relatively closer to the river mouth. In the 'around C.L.' cases (figure 4) also, when the area of heavy rainfall is closer to the river mouth (figures $4 \mathrm{c}$ and $4 \mathrm{e}$ ), the Godavari experienced severe floods. In the 'west of C.L.' case (figure 6b), though the area of heavy rainfall is closer to the river mouth, the intensity of rainfall is less.

As shown in figures 4 to 6 , the confluence line is generally situated at a distance of 200 to $600 \mathrm{~km}$ to the west of the disturbance-centre. Heavy rainfall is 

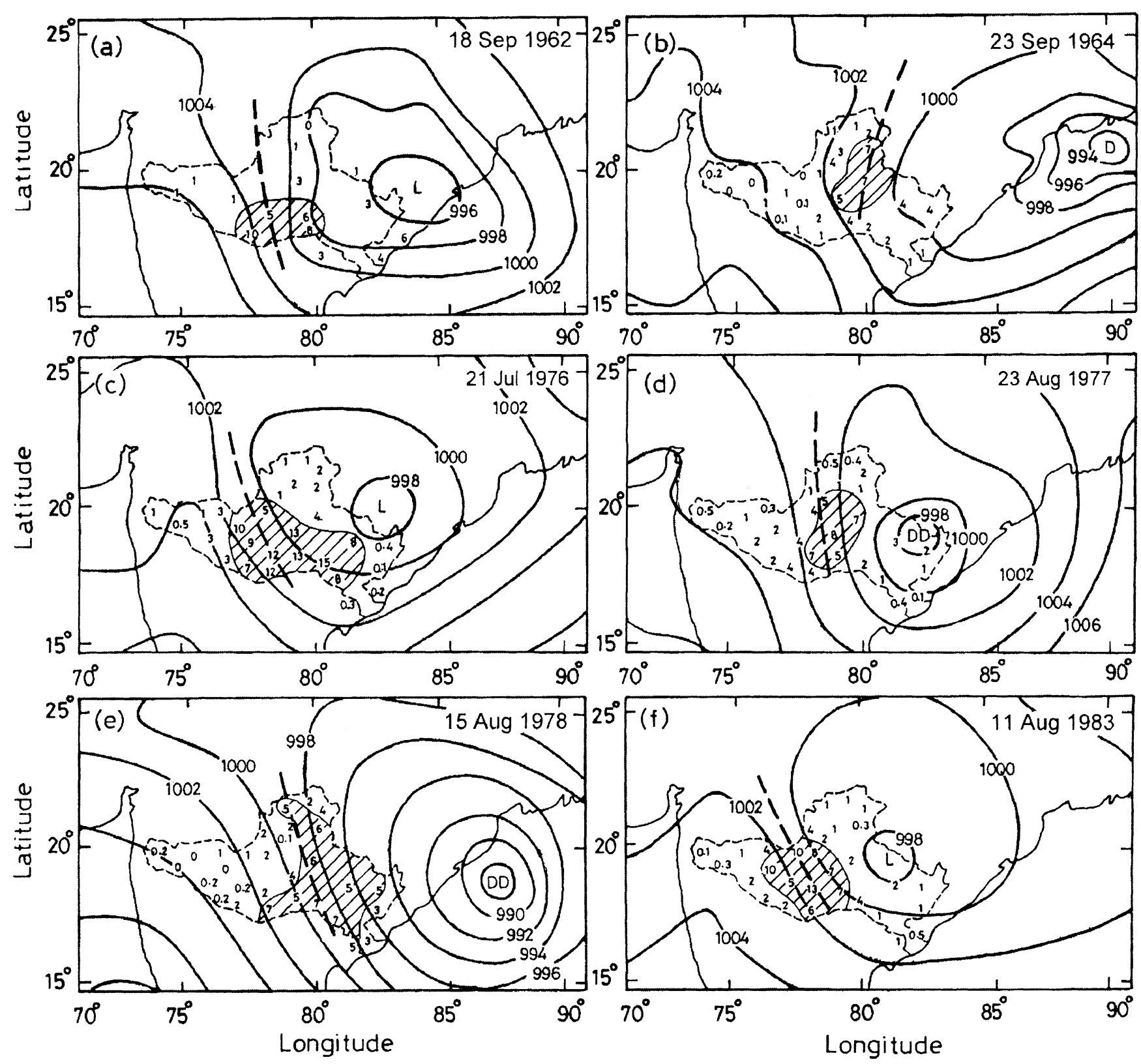

Figure 4. Surface pressure pattern and rainfall $(\mathrm{cm})$ distribution in Godavari basin on the day of maximum rainfall in the cases where the heavy rainfall occurred around the confluence line. The confluence line is indicated by a thick dotted line. The area of heavy rainfall $(>5 \mathrm{~cm})$ is hatched. D - depression, DD - deep depression.

concentrated in the downstream area where the isobar gradient is also large, either to the left or right or around the confluence line itself. It has been observed that heavy to very heavy rainfall of more than $5 \mathrm{~cm}$, in general and in some cases, even as high as $33 \mathrm{~cm}$ (figure 5c) at some stations has occurred over an area extending between 200 and $400 \mathrm{~km}$ near the confluence line. As the disturbance moves towards the west, this confluence line is also displaced to the west across different parts of the basin, causing heavy rainfall in different parts of the basin. Thus, the position and the movement of the confluence line, which is the area of heavy rainfall in the basin and on which the intensity and the raising period of the resulting flood largely depend on are important. This can be clearly seen from figure 7 , in which the sequence of a deep depression (DD) during 12th-15th August 1986, which caused the most severe flood in Godavari river on 16th August 1986, is presented along with the track of the DD (figure 7a) and the hydrograph of the resulting flood (figure $7 \mathrm{~b}$ ). As the observing site at Dowlaiswaram was submerged under flood waters, the discharge observations subsequent to the peak flood on 16th August 1986 were not observed for about a week. This missing data in the recession part of the hydrograph with no appreciable rain water during that period were generated by Subbaramayya and Nageswara Rao (1989). In figure $7(\mathrm{~b})$ this generated part of the hydrograph is represented by a dotted curve. 

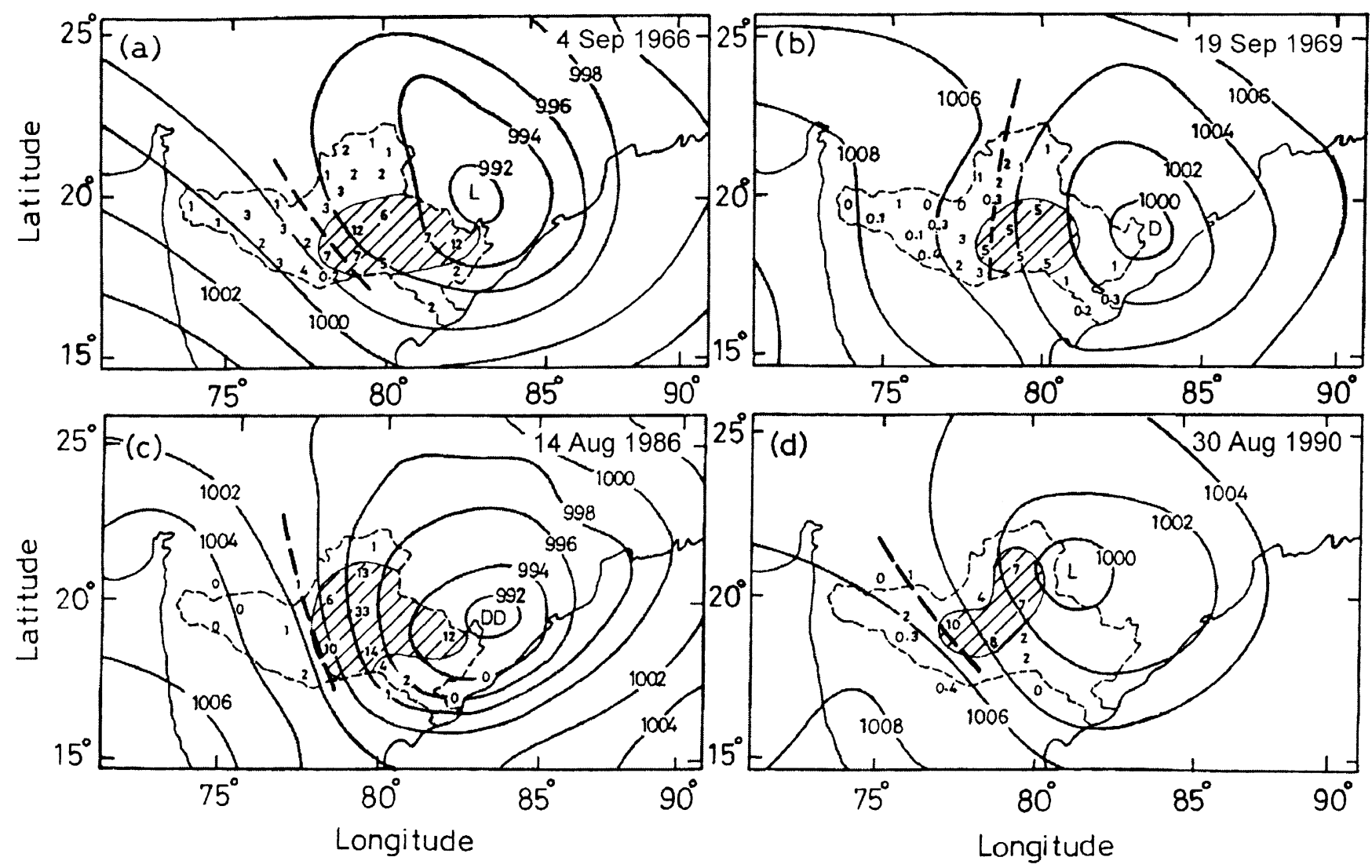

Figure 5. Same as figure 4, but for the cases where the heavy rainfall occurred to the east of the confluence line.

The DD initially formed on 11th August, as a well marked low over northwest Bay. By 12th, the low rapidly developed into a DD. On this day, the confluence line (figure 7c) between the depression winds and the general monsoon winds was oriented N-S across the eastern parts of the basin, with large isobar convergence as well as gradient. Heavy to very heavy rains occurred in the eastern parts of the basin around the confluence line, with very heavy rains of more than $20 \mathrm{~cm}$, near the river mouth. On 13th August, the centre of the DD and the confluence line moved to the west along with the area of heavy rainfall. The confluence line is now running across the western parts of the central basin. Heavy to very heavy rains occurred to the east of this line in central and southeastern parts of the basin. By 14th August, the DD slowly moved northwards and was situated close to the northeastern parts of the basin. The confluence line was situated over the same area as on the previous day. Very heavy rains registered on this day as well, to the east of the confluence line in the central and eastern parts of the basin. By 15th August, the DD weakened into a depression and was situated to the east of the

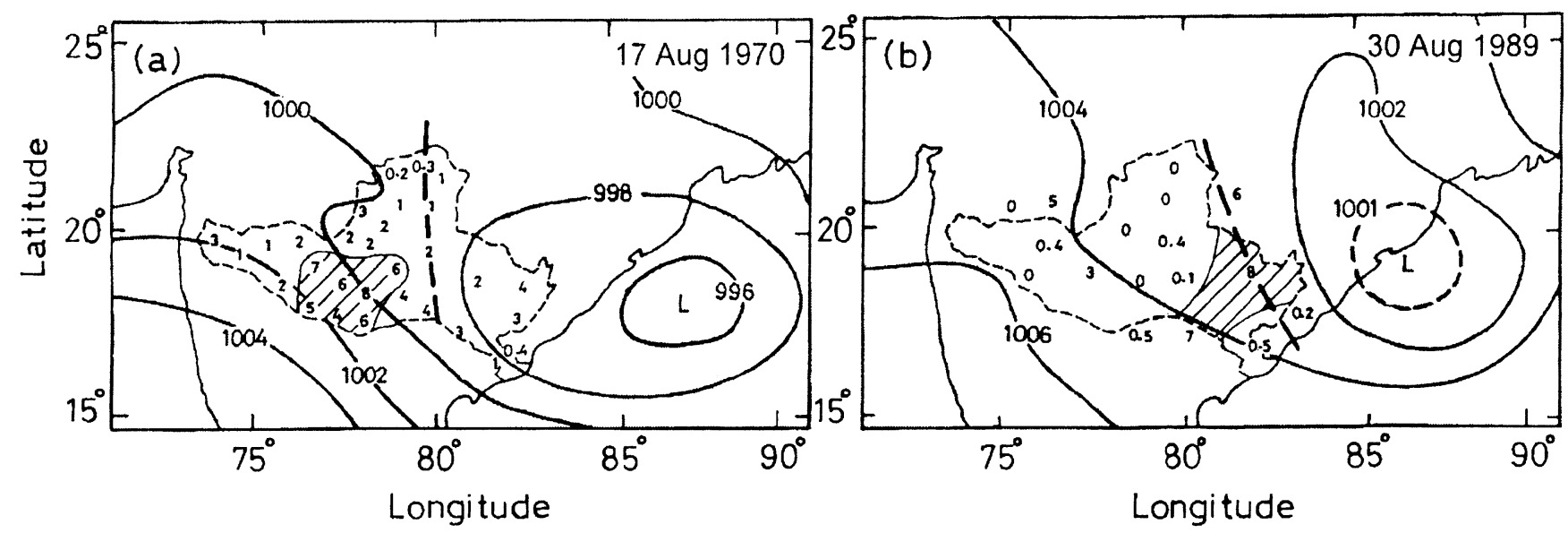

Figure 6. Same as figure 4, but for the cases where the heavy rainfall occurred to the west of the confluence line. 

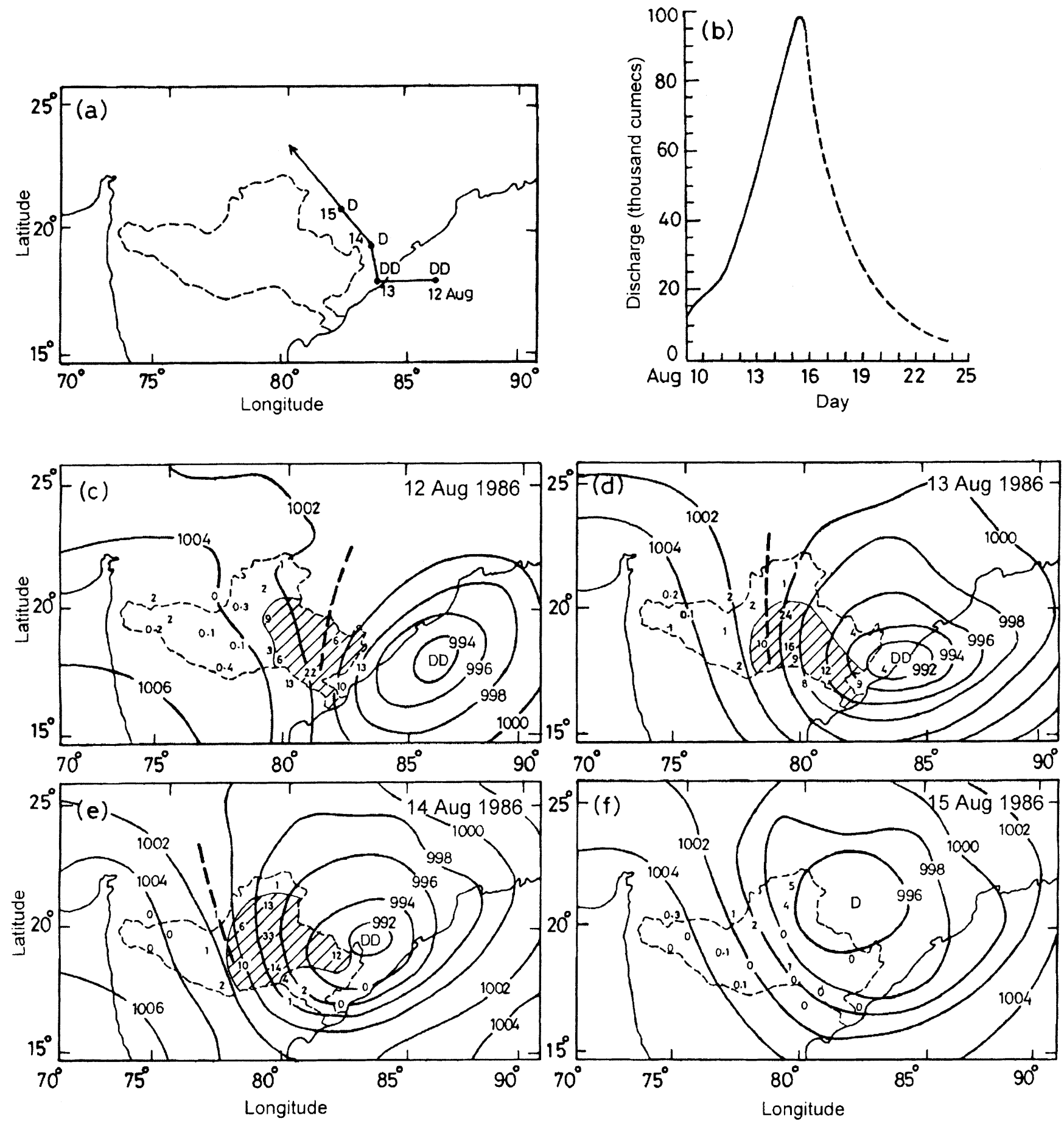

Figure 7. Sequence (c-f) of surface pressure charts of a deep depression which caused the most severe flood in Godavari, along with the track (a) and the resultant flood hydrograph (b). D - depression, DD - deep depression.

Godavari basin. The rains in the basin suddenly decreased. The hydrograph of this flood (figure $7 \mathrm{~b}$ ) shows that the discharge started rising on 11th August, when it was already at 18.5 thousand cumecs, which was due to an earlier low pressure system. The very heavy rains from 12 th to 14 th August that occurred in association with the C.L., successively over different parts of the basin from the river mouth towards the upstream, must have been responsible for the gradual increase in the river discharge from 13th to 16th August and the slightly longer rising period of the flood.

\section{Summary and conclusion}

Though the centre of the monsoon disturbances is far away from the basin area, heavy rainfall may also occur in a river basin close to the zone of confluence and may cause severe floods in the river. 
The confluence line is generally situated at a distance of 200 to $600 \mathrm{~km}$ to the west of the disturbance-centre. Depending on the vertical slope of the confluence line, the heavy rainfall may occur to the east, west or around the confluence line itself. Heavy to very heavy rainfall of more than $5 \mathrm{~cm}$ in general, and in some cases even as high as $33 \mathrm{~cm}$ occurred over an area extending between 200 and $400 \mathrm{~km}$ near the confluence line.

The position of the confluence line with respect to the basin area and its vertical slope are important in predicting the area of heavy rainfall in the river basin, on which the intensity and the raising period of the resulting flood depend.

In general, the floods resulting from the heavy rainfall associated with the confluence line are more severe than those resulting from the rainfall associated with the system centre. Also, the most severe floods in Godavari are associated with the heavy rainfall that occurs to the east of the confluence line.

\section{References}

Bedekar V C and Benarjee V C 1969 A study of climatological and other rainfall patterns over central India; Indian J. Met. and Geophys. 20 23-29

Chowdary A and Gaikwad S D 1983 On some characteristic features of rainfall associated with monsoon depressions over India; Mausam 34 33-42
Dhar O N, Mulye S S and Nandargi S 1987 Was the lower Godavari basin rainstorm of August 1986 unprecedented?; A quaworld 384-390

Lal S S 1958 Rainfall around slow moving monsoon depressions over India; Proc. Symp. on Meteorological and Hydrological aspects of floods and droughts in India, p. 53.

Nageswara Rao G 1998 Interannual variations of monsoon rainfall in Godavari river basin - Connections with the Southern Oscillation; J. Climate 11 768-771

Nageswara Rao 1999 Interannual variations of monsoon rainfall and the available water resource in Godavari river basin; J Appl. Hydrology XII 52-58.

Nageswara Rao and Subbaramayya I 1991 A note on the hydrometeorology of August 1990 floods in Godavari; Indian Journal of Power and River Valley Develop XLI 75-78

Pisharoty P R and Asnani G C 1957 Rainfall around monsoon depressions over India; Indian J. Met. and Geophys. 8 15-20

Ramaswamy C 1987 Meteorological aspects of severe floods in India, 1923-1979; Meteorological Monograph, 10/1987, India Meteorological Department.

Ramaswamy C and Subba Rao V 1980. Record discharge and severe floods in Godavari; Curr. Sci. XLIX 571-578.

Rao Y P 1976. Southwest monsoon; Meteorological Monograph, Synoptic Met. No. 1/1976, India Meteorological Department.

Rao K N and Jayaraman S 1958 A statistical study of frequency of depressions/cyclones in the Bay of Bengal; Indian Journal Met. and Geophys. 9 233-250

Subbaramayya I and Nageswara Rao G 1989 Hydrometeorological aspects of the 1986 floods in Godavari river; Indian Journal of Power and River Valley Develop. XXXIX 202-209.

Venkataraman K S, Chowdary A and Banerjee A K 1974 A study of hourly rainfall distribution around monsoon depression centre in central India; Indian J. Met. and Geophys. 25 239-244 